\title{
In vitro evaluation of Rhus succedanea extracts for ruminants
}

\author{
Do Hyung Kim ${ }^{1, a}$, Shin Ja Lee, ${ }^{2, a}$, Da Som Oh ${ }^{3}$ Il Dong Lee ${ }^{3}$, Jun Sik Eom ${ }^{3}$, Ha Young Park', \\ Seong Ho Choi ${ }^{5}$, and Sung Sill Lee ${ }^{3, *}$
}

\author{
* Corresponding Author: Sung Sill Lee \\ Tel: +82-55-772-1883, Fax: +82-55-772-1889, \\ E-mail: Iss@gnu.ac.kr \\ 'Department of Animal Science, Gyeongbuk Provincia \\ College, Yecheon 36830, Korea \\ 2 Institute of Agriculture and Life Science and \\ University-Centered Labs, Gyeongsang National \\ University, Jinju 52828, Korea \\ ${ }^{3}$ Division of Applied Life Science (BK21 Program) \\ and Institute of Agriculture \& Life Science (IALS), \\ Gyeongsang National University, Jinju 52828, Korea \\ ${ }^{4}$ Department of Pathology, Busan Paik Hospital, Inje \\ University College of Medicine, Busan 47392, Korea \\ ${ }^{5}$ Department of Animal Science, Chungbuk National \\ University, Cheongju 28644, Korea \\ a These authors contributed equally to this work and \\ co-first authors.

\section{ORCID} \\ Do Hyung Kim \\ https://orcid.org/0000-0002-0726-8531 \\ Shin Ja Lee \\ https://orcid.org/0000-0002-4224-1211 \\ Da Som Oh \\ https://orcid.org/0000-0003-1902-8129 \\ Il Dong Lee \\ https://orcid.org/0000-0003-1221-4383 \\ Jun Sik Eom \\ https://orcid.org/0000-0001-5360-0147 \\ Ha Young Park \\ https://orcid.org/0000-0002-7192-2374 \\ Seong Ho Choi \\ https://orcid.org/0000-0003-1026-1485 \\ Sung Sill Lee \\ https://orcid.org/0000-0002-4621-4333
}

Submitted Jan 10, 2018; Revised Feb 13, 2018 ; Accepted Apr 10, 2018
Objective: This study was conducted to evaluate the effects of Rhus succedanea extract addition on in vitro ruminal fermentation and microbial growth.

Methods: Two ruminally-fistulated steers consuming $600 \mathrm{~g} / \mathrm{kg}$ timothy- and $400 \mathrm{~g} / \mathrm{kg}$ cracked corn-based concentrate with free access to water and mineral block were used as rumen fluid donors. In vitro batch fermentation, with timothy as a substrate, was conducted for up to $72 \mathrm{~h}$, with Rhus succedanea extracts added to achieve final concentrations of $0,10,30,50,70$, and $90 \mathrm{mg} / \mathrm{L}$.

Results: Effective dry matter $(\mathrm{DM})$ degradability rate linearly decreased $(\mathrm{p}=0.046)$ depending on extract dosing levels. Total gas production after 24 to $72 \mathrm{~h}$ incubation tended to decrease following extract addition, beginning with $50 \mathrm{mg} / \mathrm{L}$ starting dose (significance of quadratic effects: $\mathrm{p}=0.006, \mathrm{p}<0.001$, and $\mathrm{p}=0.008$ for 24,48 , and $72 \mathrm{~h}$, respectively). Methane production decreased depending on dosing levels following $24 \mathrm{~h}(\mathrm{p}<0.05)$ and $48 \mathrm{~h}(\mathrm{p}<0.005)$ incubations and was the lowest with the $50 \mathrm{mg} / \mathrm{L}$ dose. The Rhus succedanea extracts increased the abundance of Fibrobacter succinogenes $(\mathrm{p}<0.05)$ and Ruminococcus flavefaciens $(\mathrm{p}=0.0597)$ and decreased the abundance of methanogenic archaea $(\mathrm{p}<0.05)$ following $24 \mathrm{~h}$ incubation. Conclusion: Rhus succedanea was shown to reduce methane production and increase cellulolytic bacteria without any signs of toxic effects and with a minor effect on DM degradability.

Keywords: Rhus succedanea Extracts; In vitro Ruminal Fermentation; Microbial Growth

\section{INTRODUCTION}

The efficiency of ruminal fermentation can be facilitated by modifying the feeding regime of ruminants using natural feed additives. A number of methanogenic inhibitors have been developed to improve feed conversion efficiency of ruminant feeds, which are claimed to be effective in suppressing methanogens or overall bacterial activities [1]. However, some compounds are toxic or may not be economically feasible, or an adaptive response may occur in some bioactive compounds after supplementation.

In recent years, there has been a global trend toward the use of natural plants as medicinal and functional food additives. Medicinal plants have various characteristics, such as antimicrobial, antiviral, and immune system stimulating activities, which can be beneficial to animal health and production. Rhus succedanea, the wax tree, is a flowering plant species found in Asia. Rhus succedanea (formerly Toxicodendron succedaneum) has been used in indigenous medicine for quite a long time in the treatment of asthma, cough, and colicky pains [2], and has anti-rumor, anti-oxidation, hangover cure, and gastritis suppression effects [3]. Bioactive constituents from R. succedanea have been isolated and characterized. These mostly include urushiol, flavonoids, and phenols [3].

Although a number of studies using plant extracts have been conducted to apply them as feed additives, $R$. succedanea extracts have rarely been applied to ruminant animals. Kim 
et al [4] reported that dietary Rhus verniciflua supplementation of Hanwoo cattle feed was effective in increasing meat color stability, water-holding capacity, and unsaturated fatty acid content, as well as retarding lipid oxidation. However, information on the effects of application of R. succedanea on ruminal fermentation is limited. Therefore, this study was conducted to evaluate the effects of $R$. succedanea extracts on in vitro ruminal metabolites, gas production, and microbial growth.

\section{MATERIALS AND METHODS}

\section{Sample preparation}

Rhus succedanea extracts were obtained from the Plant Extract Bank (KRIBB, Daejeon, Korea). R. succedanea was cut into small pieces and dried naturally under shade. Extraction from the dried pieces (100 g each) was then performed with $99.9 \%$ methyl alcohol (1,000 $\mathrm{mL}$ ) using an ultrasonic cleaner (Branson Ultrasonics Corporation, Danbury, CT, USA) at room temperature for three days. After extraction, the solutions were filtered and the solvents were evaporated under vacuum conditions. Stock solution $(20 \mathrm{mg} / \mathrm{mL})$ of the extracts was dissolved in dimethyl sulfoxide (Sigma-Aldrich Chemical Co., St. Louis, MO, USA) and diluted using culture medium immediately before in vitro incubation. $R$. succedanea extracts were prepared to achieve final dosing concentrations of $0,10,30,50$, 70 , and $90 \mathrm{mg} / \mathrm{L}$.

\section{In vitro batch fermentation}

Ruminal contents were collected from two ruminally-fistulated steers (with mean body weight \pm standard error of $450 \pm 30 \mathrm{~kg}$ ), which had been consuming $600 \mathrm{~g} / \mathrm{kg}$ body weight timothy and $400 \mathrm{~g} / \mathrm{kg}$ cracked corn-based concentrate (crude protein, $120 \mathrm{~g} / \mathrm{kg}$; ether extracts, $15 \mathrm{~g} / \mathrm{kg}$; crude fiber, $150 \mathrm{~g} / \mathrm{kg}$; crude ash, $120 \mathrm{~g} / \mathrm{kg} ; \mathrm{Ca}, 7.5 \mathrm{~g} / \mathrm{kg} ; \mathrm{P}, 9.0 \mathrm{~g} / \mathrm{kg}$; total digestible nutrients, $690 \mathrm{~g} / \mathrm{kg}$ dry matter [DM] basis) with free access to water and mineral block (supplied per kilogram of diet: vitamin [Vit] A, 3,800 IU; Vit E, 400 IU; Vit E, $500 \mathrm{IU} ; \mathrm{Fe}, 7 \mathrm{mg}$; Cu, $2.4 \mathrm{mg}$; Mn, $30 \mathrm{mg}$; Zn, $6.0 \mathrm{mg}$; I, $1.5 \mathrm{mg}$; Se and Co, $1.5 \mathrm{mg}$ ). The diet was fed at $3 \%$ of body weight of the steers in two equal portions at $07 \mathrm{~h} 00$ and $17 \mathrm{~h} 00$ daily. The steers were acclimated to the diet for a minimum of 14 days.

On the day of fermentation testing, approximately $2 \mathrm{~kg}$ of ruminal contents were collected from the dorsal, ventral, and caudal rumen of each steer $2 \mathrm{~h}$ after the morning feeding, and collected into an insulated container for transport to the laboratory, usually within $10 \mathrm{~min}$ after collection. Ruminal contents were processed with a Waring blender under a $\mathrm{CO}_{2}$ atmosphere and strained through four layers of cheesecloth and glass wool prior to combining with McDougall buffer [5]. The McDougall buffer $(1,000 \mathrm{~mL})$ and ruminal inoculums (500 $\mathrm{mL}$ ) were combined, and $25 \mathrm{~mL}$ of this mixture was then added to 60 - $\mathrm{mL}$ fermentation vessels (serum bottles) containing 0 or $300 \mathrm{mg}$ (based on DM) of substrate. The substrate was supplied from the timothy that was fed to the steers, and was used after being ground up in a Wiley mill until it could pass through a $2 \mathrm{~mm}$ screen. The fermentation vessels were closed with butyl rubber stoppers under the anaerobic gassing systems while being connected to a source of oxygen-free gas, and then were sealed with aluminum caps and placed in an incubator at $39^{\circ} \mathrm{C}$ for $3,6,9,12,24,48$, and $72 \mathrm{~h}$ without shaking. Fermentation was conducted in a completely randomized order and in duplicate for each sample, and was then replicated on three separate days ( $\mathrm{n}=3$ for each dose in statistical analyses).

Total gas and methane production, ammonia-nitrogen, and volatile fatty acid content

At the end of each incubation, a detachable pressure transducer and a digital readout voltmeter (Laurel Electronics, Inc., Costa Mesa, CA, USA) were used to measure the headspace gas pressure in each vessel. Gas samples for methane analysis were drawn from each vessel into sampling syringes and transferred into a vacuum test tube (Vacutainer, Becton Dickinson, Franklin Lakes, NJ, USA). Gas samples were analyzed for methane concentrations by gas chromatography (Agilent Technologies HP 5890, Santa Clara, CA, USA) conducted using a thermal conductivity detector with a Column Carboxen 1006PLOT capillary column, measuring $30 \mathrm{~m} \times 0.53$ $\mathrm{mm}$ (Supelco, Bellefonte, PA, USA), as described by Zafarian and Manafi [6].

After determination of gas production, the vessels were uncapped, the $\mathrm{pH}$ of fermentation media was then measured, and a $5-\mathrm{mL}$ aliquot of the fermentation medium was combined with $0.5 \mathrm{~mL}$ of 2-ethylbutyrate $(85 \mathrm{mM})$ as an internal standard and $0.5 \mathrm{~mL}$ of $50 \mathrm{~g} / \mathrm{kg}$ metaphosphoric acid for analysis of volatile fatty acid (VFA) concentrations. These samples were centrifuged at $39,000 \times \mathrm{g}$ at $23^{\circ} \mathrm{C}$ for $15 \mathrm{~min}$, transferred to vials, capped, and analyzed for VFA concentrations by gas chromatography (model GC-14B, Shimadzu Co. Ltd., Tokyo, Japan) using a Thermon-3000 5\% Shincarbon A columm (1.6 $\mathrm{m} \times 3.2 \mathrm{~mm}$ i.d., 60 to $80 \mathrm{mesh}$, Shinwakako, Kyoto, Japan) and flame-ionization detector (column temperature $=130^{\circ} \mathrm{C}$, injector and detector temperature $=200^{\circ} \mathrm{C}$ ). The carrier gas $\left(\mathrm{N}_{2}\right)$ flow rate was $50 \mathrm{~mL} / \mathrm{min}$. A 5-mL aliquot of the fermentation medium was combined with $0.5 \mathrm{~mL}$ of $25 \mathrm{~g} / \mathrm{kg}$ metaphosphoric acid for analysis of $\mathrm{NH}_{3}-\mathrm{N}$ concentration using a spectrophotometer (Model 680, Bio-Rad Laboratories, Hercules, CA, USA) and methods based on glutamate dehydrogenase.

\section{Relative quantification of specific ruminal microbes} Total nucleic acid was extracted from the incubated rumen samples using the modified bead-beating protocol with the 
Soil kit (Macherey-nagel, Düren, Germany). This was accomplished by taking a $1.0-\mathrm{mL}$ aliquot from the culture medium using a wide-bore pipette to ensure collection of a homogeneous sample, and then centrifugating the aliquot at 39,000 $\mathrm{xg}$. Nucleic acid concentrations were measured using a NanoDrop Spectrophotometer (Thermo Scientific, Wilmington, DE, USA).

Polymerase chain reaction (PCR) primer sets were then used in this study to detect and amplify DNA from Fibrobacter succinogenes (forward primer: GTT CGG AAT TAC TGG GCG TAA A; reverse primer: CGC CTG CCC CTG AAC TAT C), Ruminococcus flavefaciens (forward primer: CGA ACG GAG ATA ATT TGA GTT TAC TTA GG, reverse primer: CGG TCT CTG TAT GTT ATG AGG TAT TAC C), and Ruminococcus albus (forward primer: CCC TAA AAG CAG TCT TAG TTC G; reverse primer: CCT CCT TGC GGT TAG AAC A), and the primers used were the same as those referenced by Denman and McSweeney [7], Koike and Kobayashi [8], and Skillman et al [9], respectively. A total bacteria primer set (forward: CGG CAA CGA GCG CAA CCC; reverse: CCA TTG TAG CAC GTG TGT AGC C) was used as the internal standard [7].

Real-time PCR (RT-PCR) assays for enumeration of microbes were performed according to the methods described by Denman and McSweeney [7] and Denman et al [10] on a real-time PCR Machine (CFX96 Real-Time system, Bio-Rad, USA) using the SYBR Green Supermix (QPK-201, Toyobo Co., Ltd., Tokyo, Japan). The values of the cycle threshold (Ct) after PCR reactions were used to determine fold change (number of fold difference) of different microbial populations relative to the control without additives. Abundance of these microbes was expressed by the equation: relative quantification $=2^{-\Delta \mathrm{Ct} \text { (Target) }-\Delta \mathrm{Ct} \text { (Control) }}$, where $\mathrm{Ct}$ represents the threshold cycle. All RT-PCR reaction mixtures (final volume of $25 \mu \mathrm{L}$ ) contained forward and reverse primers (10 pmol each), the SYBR Green Supermix (QPK-201, Toyobo Co., Ltd., Japan), and DNA templates ranging from 10 to $100 \mathrm{ng}$. A negative control without template DNA was used in every RT-PCR assay for each primer. The amplification of the target DNA was performed as described by Denman and McSweeney [7], Koike and Kobayashi [8], and Skillman et al [9].

\section{Calculations and statistical analysis}

To give a more precise estimate of gas production throughout fermentation, the following calculation was used to analyze the kinetic data, as described by Ørskov and McDonald [11]: $\mathrm{G}_{\mathrm{P}}=\mathrm{a}+\mathrm{b}\left(1-\exp ^{-\mathrm{cxtime}}\right)$, where $\mathrm{G}_{\mathrm{P}}$ is gas production $(\mathrm{mL} / \mathrm{g} \mathrm{DM}$ of substrate) at time t; a, b, and c are the scaling factors for the Y-axis intercept $(\mathrm{mL} / \mathrm{g}$ of $\mathrm{DM})$, potential gas production $(\mathrm{mL} / \mathrm{g}$ of DM), and the rate constant for gas production per h, respectively. Gas production rate was fitted to the model by using the NLIN procedure of SAS (version 9.1, SAS Inst. Inc., Cary, NC, USA) employing Marquadt's algorithm, while varying a, $\mathrm{b}$, and c. Effective gas production ( $\mathrm{EG}_{\mathrm{p}}$ i.e. substrate availability) from the culture was estimated as $E G_{p}=a+b\left(k_{d} /\left[k_{d}+k_{p}\right]\right)$, where $\mathrm{k}_{\mathrm{d}}$ is a gas production rate constant, and $\mathrm{k}_{\mathrm{p}}$ is a passage rate constant assumed to be $0.05 / \mathrm{h}$ [12].

Data obtained from the experiment were analyzed using the general linear model procedure of SAS (SAS Inst. Inc., USA) for a completely random design. The model included terms for dosing levels, time, and their interaction. Orthogonal contrast was used to assess linear, quadratic, and cubic relationships between the dosing levels of R. succedanea extracts and the dependent variables. Orthogonal coefficients for unequally spaced dosing were acquired using the IML procedure (SAS Inst. Inc., USA).

\section{RESULTS}

Table 1 shows the effects of different doses of $R$. succedanea extracts on DM degradability and their parameters after different incubation periods. The DM degradability was not affected by the dose of $R$. succedanea extracts, except after 24 and $72 \mathrm{~h}$ incubations, when it decreased by dose (significance of linear effect: $p=0.04$; linear and cubic effects: $p=0.014$ and $\mathrm{p}=0.041$, respectively). The DM degradability for 24 and 72 $\mathrm{h}$ incubations was decrease by 70 and $90 \mathrm{mg} / \mathrm{L}$ doses of $R$. succedanea extracts. Effective DM degradability rate $\left(\mathrm{E}_{\mathrm{DM}}\right)$ decreased linearly with dose $(\mathrm{p}=0.046)$. Cumulative gas production rapidly increased from 12 to $72 \mathrm{~h}$ of incubation (Table 2). The $R$. succedanea extracts increased total gas production depending on dosing level at 24 (linear, quadratic, and cubic effects: $\mathrm{p}=0.005,0.006$, and 0.051 , respectively), 48 (quadratic effect: $\mathrm{p}<0.001$ ), and $72 \mathrm{~h}$ (quadratic and cubic effects: $\mathrm{p}=$ 0.008 and 0.031 , respectively) incubations. In addition, the total gas production for 24 to $72 \mathrm{~h}$ incubation tended to decrease with $50 \mathrm{mg} / \mathrm{L}$ dosing of $R$. succedanea extract as a starting point (quadratic effects: $p=0.006, p<0.001$, and $p=0.008$ for 24,48 , and $72 \mathrm{~h}$, respectively). The potential gas production $(\mathrm{a}+\mathrm{b})$ was decreased (cubic effect: $\mathrm{p}=0.051$ ) by dosing with $50 \mathrm{mg} / \mathrm{L}$ of $R$. succedanea extracts. The decrease in the potential gas production led to an increase in the $k$ value. Effective gas production rate $\left(\mathrm{E}_{\mathrm{Gp}}\right)$ was decreased (linear and quadratic effects: $p=0.003$ and 0.069 , respectively) depending on dosing levels.

The $\mathrm{pH}$ was slightly increased after fermentation depending on the dose used at $24 \mathrm{~h}$ and $72 \mathrm{~h}$, but remained within an optimal pH range of 6 to 7 (Table 3). Ammonia-N concentration changed in a quadratic manner $(\mathrm{p}=0.003)$ following $24 \mathrm{~h}$ incubation, which was increased by $50 \mathrm{mg} / \mathrm{L}$ of $R$. succedanea extracts. Total VFA concentration was decreased by $50 \mathrm{mg} / \mathrm{L}$ of $R$. succedanea extracts following $48 \mathrm{~h}$ (quadratic effect: $\mathrm{p}=0.021$ ) and by 70 and $90 \mathrm{mg} / \mathrm{L}$ of $R$. succedanea extracts following $72 \mathrm{~h}$ incubation (linear effect: $\mathrm{p}=0.014$ ). Total VFA concentration following $24 \mathrm{~h}$ of incubation de- 
Table 1. Effects of different doses of Rhus succedanea extracts on in vitro dry matter degradability by mixed rumen anaerobic microbial fermentation

\begin{tabular}{|c|c|c|c|c|c|c|c|c|c|c|}
\hline \multirow{2}{*}{ Incubation time } & \multicolumn{6}{|c|}{ Dose (mg/L) } & \multirow{2}{*}{ SEM } & \multicolumn{3}{|c|}{ Contrast } \\
\hline & 0 & 10 & 30 & 50 & 70 & 90 & & Linear & Quadratic & Cubic \\
\hline \multicolumn{11}{|c|}{ Dry matter degradability (\%) } \\
\hline $3 \mathrm{~h}$ & 18.84 & 19.32 & 18.75 & 17.98 & 18.41 & 18.15 & 0.25 & 0.006 & 0.443 & 0.314 \\
\hline $6 \mathrm{~h}$ & 19.44 & 18.89 & 18.69 & 19.82 & 19.20 & 19.31 & 0.37 & 0.586 & 0.889 & 0.182 \\
\hline $9 \mathrm{~h}$ & 20.42 & 20.26 & 20.11 & 19.01 & 19.60 & 20.14 & 0.50 & 0.326 & 0.126 & 0.426 \\
\hline $12 \mathrm{~h}$ & 18.79 & 19.04 & 18.33 & 18.79 & 18.46 & 18.02 & 0.68 & 0.370 & 0.827 & 0.748 \\
\hline $24 \mathrm{~h}$ & 23.01 & 23.57 & 21.28 & 23.55 & 21.04 & 21.94 & 0.56 & 0.040 & 0.648 & 0.977 \\
\hline $48 \mathrm{~h}$ & 34.91 & 35.68 & 34.12 & 30.95 & 35.12 & 34.54 & 1.15 & 0.514 & 0.086 & 0.815 \\
\hline $72 \mathrm{~h}$ & 42.13 & 39.89 & 39.36 & 40.05 & 39.66 & 38.97 & 0.61 & 0.014 & 0.250 & 0.041 \\
\hline \multicolumn{11}{|c|}{ Dry matter degradability parameters ${ }^{11}$} \\
\hline$a(\%)$ & 8.87 & 8.08 & 8.67 & 7.49 & 8.71 & 8.23 & 0.58 & 0.673 & 0.512 & 0.686 \\
\hline$b(\%)$ & 35.20 & 31.80 & 32.47 & 31.53 & 33.17 & 31.57 & 1.52 & 0.317 & 0.485 & 0.236 \\
\hline$a+b(\%)$ & 44.07 & 39.88 & 41.15 & 39.02 & 41.89 & 39.77 & 2.07 & 0.388 & 0.491 & 0.319 \\
\hline$k\left(D_{M} / h\right)$ & 0.0325 & 0.0425 & 0.0347 & 0.0527 & 0.0325 & 0.0390 & 0.01 & 0.856 & 0.496 & 0.755 \\
\hline$E_{D M}$ & 22.49 & 22.69 & 21.66 & 21.90 & 21.72 & 21.85 & 0.31 & 0.046 & 0.181 & 0.942 \\
\hline
\end{tabular}

SEM, standard error of the mean, $n=3$.

1) Potential extent and rate of dry matter degradability were determined using the exponential model: $D_{M}=a+b\left(1-e x p^{-c x t i m e}\right)$, where $D_{M}$ is dry matter degradability $(\%)$ at time $t ;$ $a=$ dry matter degradability from the immediately soluble fraction; $b=$ dry matter degradability from the insoluble fraction; $c=$ the fractional rate of dry matter degradability per hour; $a+b=$ potential extent of dry matter degradability; $E_{D M}=$ effective dry matter degradability rate from the cultures, calculated as $E_{D M}=a+b\left[k_{d} /\left(k_{d}+k_{p}\right)\right]$, where $k_{d}$ is a dry matter degradability rate constant, and $k_{p}$ is a passage rate constant assumed to be $0.05 \mathrm{~h}^{-1}$.

creased $(\mathrm{p}<0.05)$ and acetate concentration increased $(\mathrm{p}<0.05)$ relative to control with dosing of $70 \mathrm{mg} / \mathrm{L}$ of $R$. succedanea extracts (Figure 1). No differences were observed in propionate and butyrate concentrations and acetate to propionate ratio. Methane production was decreased depending on dosing levels following $24 \mathrm{~h}$ (linear and quadratic effects: $\mathrm{p}<0.0001$ and $p=0.002$, respectively) and $48 \mathrm{~h}$ (linear and cubic effects: $\mathrm{p}<0.0001$ and $\mathrm{p}<0.001$, respectively; Table 4 ) incubations, and was the lowest at $50 \mathrm{mg} / \mathrm{L}$ doses of $R$. succedanea extract.
Real-time PCR analyses indicated that $R$. succedanea extracts affected the abundance of cellulolytic bacteria and methanogenic archaea (Figure 2). The dose of R. succedanea extracts increased the abundance of Fibrobacter succinogenes (linear, quadratic, and cubic effects: $\mathrm{p}<0.0001, \mathrm{p}=0.0006$, and $\mathrm{p}=$ 0.0078, respectively) and Ruminococcus flavefaciens (linear effect: $p=0.0597$ ), and decreased the abundance of methanogenic archaea (linear and quadratic effects: $p<0.0001$ and $\mathrm{p}=0.0073$, respectively) after $24 \mathrm{~h}$ of incubation.

Table 2. Effects of different doses of Rhus succedanea extracts on in vitro cumulative gas production by mixed rumen anaerobic microbial fermentation

\begin{tabular}{|c|c|c|c|c|c|c|c|c|c|c|}
\hline \multirow{2}{*}{ Incubation time } & \multicolumn{6}{|c|}{ Dose (mg/L) } & \multirow{2}{*}{ SEM } & \multicolumn{3}{|c|}{ Contrast } \\
\hline & 0 & 10 & 30 & 50 & 70 & 90 & & Linear & Quadratic & Cubic \\
\hline \multicolumn{11}{|c|}{ Gas production (mL/0.1 g DM of substrate) } \\
\hline $3 \mathrm{~h}$ & 14.31 & 14.41 & 14.43 & 14.31 & 14.23 & 14.21 & 0.08 & 0.085 & 0.285 & 0.228 \\
\hline $6 \mathrm{~h}$ & 15.30 & 15.40 & 15.26 & 15.16 & 15.35 & 15.17 & 0.11 & 0.315 & 0.885 & 0.746 \\
\hline $9 \mathrm{~h}$ & 16.03 & 16.28 & 15.47 & 15.83 & 15.00 & 16.08 & 0.22 & 0.100 & 0.023 & 0.058 \\
\hline $12 \mathrm{~h}$ & 17.29 & 16.77 & 16.85 & 16.74 & 16.63 & 16.18 & 0.21 & 0.006 & 0.744 & 0.202 \\
\hline $24 \mathrm{~h}$ & 19.08 & 19.32 & 19.34 & 19.33 & 18.90 & 18.86 & 0.09 & 0.005 & 0.006 & 0.051 \\
\hline $48 \mathrm{~h}$ & 24.99 & 25.31 & 24.85 & 21.13 & 25.64 & 25.64 & 0.42 & 0.786 & $<0.001$ & 0.240 \\
\hline $72 \mathrm{~h}$ & 31.34 & 32.14 & 32.70 & 32.34 & 31.72 & 31.72 & 0.28 & 0.872 & 0.008 & 0.031 \\
\hline \multicolumn{11}{|l|}{ Gas production parameters ${ }^{11}$} \\
\hline $\mathrm{a}$ (mL/0.1 g DM of substrate) & 4.80 & 5.41 & 5.85 & 4.47 & 5.71 & 5.67 & 0.30 & 0.182 & 0.782 & 0.096 \\
\hline b (mL/0.1 g DM of substrate) & 22.83 & 23.47 & 23.95 & 21.74 & 23.77 & 23.64 & 0.30 & 0.345 & 0.207 & 0.046 \\
\hline$a+b(\mathrm{~mL} / 0.1 \mathrm{~g}$ DM of substrate) & 27.63 & 28.87 & 29.80 & 26.21 & 29.47 & 29.30 & 0.56 & 0.221 & 0.400 & 0.051 \\
\hline$k\left(G_{p} / h\right)$ & 0.0721 & 0.0608 & 0.0517 & 0.0838 & 0.0524 & 0.0541 & 0.01 & 0.212 & 0.530 & 0.170 \\
\hline$E_{G p}$ & 18.24 & 18.27 & 18.02 & 17.84 & 17.85 & 17.92 & 0.98 & 0.003 & 0.069 & 0.408 \\
\hline
\end{tabular}

SEM, standard error of the mean, $n=3$; DM, dry matter.

1) Potential extent and rate of gas production were determined using the exponential model: $G_{p}=a+b\left(1-\exp ^{-c x t i m e}\right.$ ), where $G_{p}$ is gas production (mL/g DM of substrate) at time $t ; a=$ gas production from the immediately soluble fraction; $b=$ gas production from the insoluble fraction; $c=$ the fractional rate of gas production per hour; $a+b$ $=$ potential extent of gas production; $\mathrm{k}=$ gas production rate constant for the insoluble fraction; $\mathrm{E}_{\mathrm{GP}}=$ effective gas production rate from the cultures, calculated as $\mathrm{E}_{\mathrm{GP}}=$ $a+b\left[k_{d} /\left(k_{d}+k_{p}\right)\right]$, where $k_{d}$ is a gas production rate constant, and $k p$ is a passage rate constant assumed to be $0.05 \mathrm{~h}^{-1}$. 
Table 3. Effects of different doses of Rhus succedanea extracts on in vitro pH, and ammonia-N and total volatile fatty acid concentrations by mixed rumen anaerobic microbial fermentation

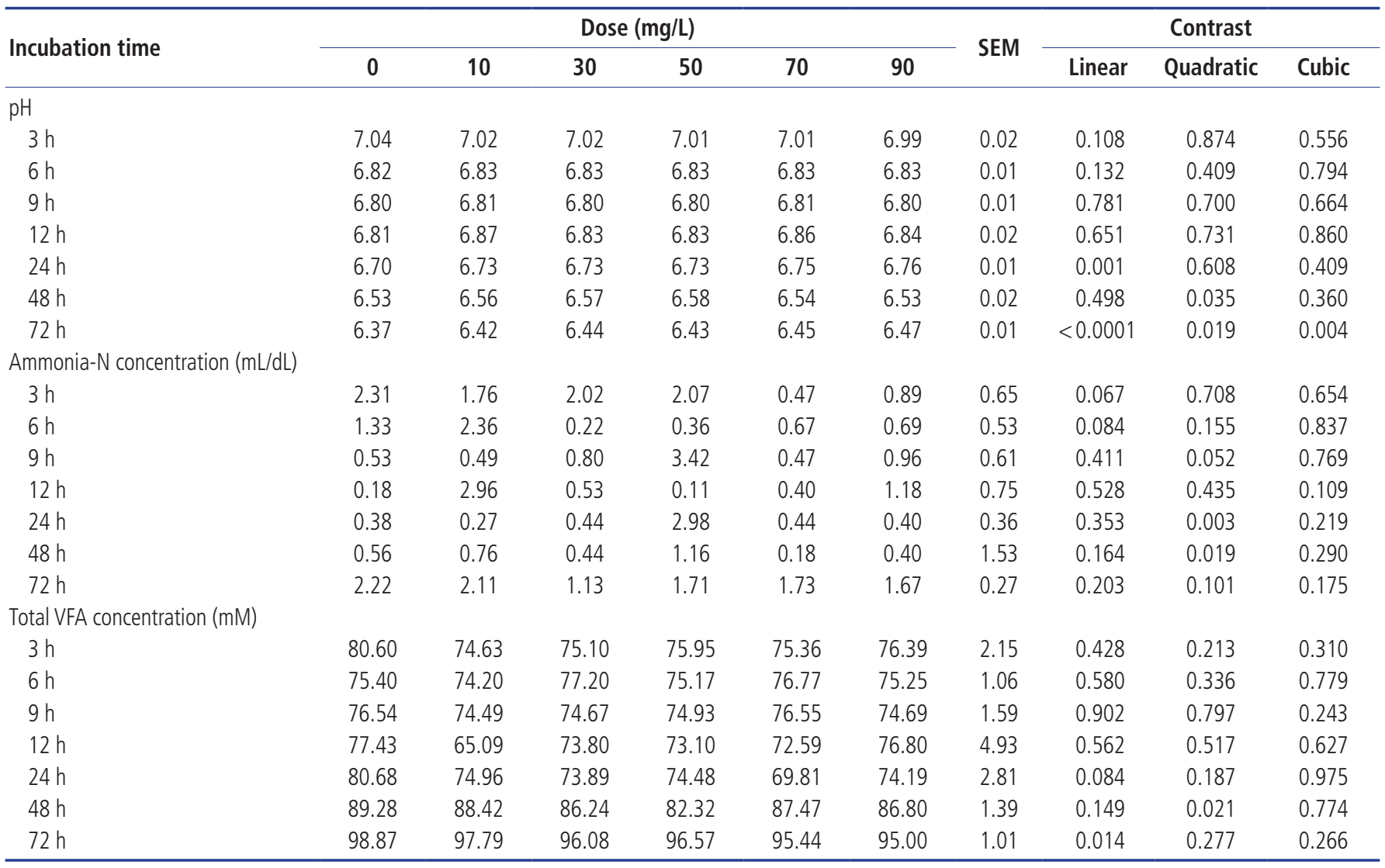

SEM, standard error of the mean, $n=3 ;$ VFA, volatile fatty acid.

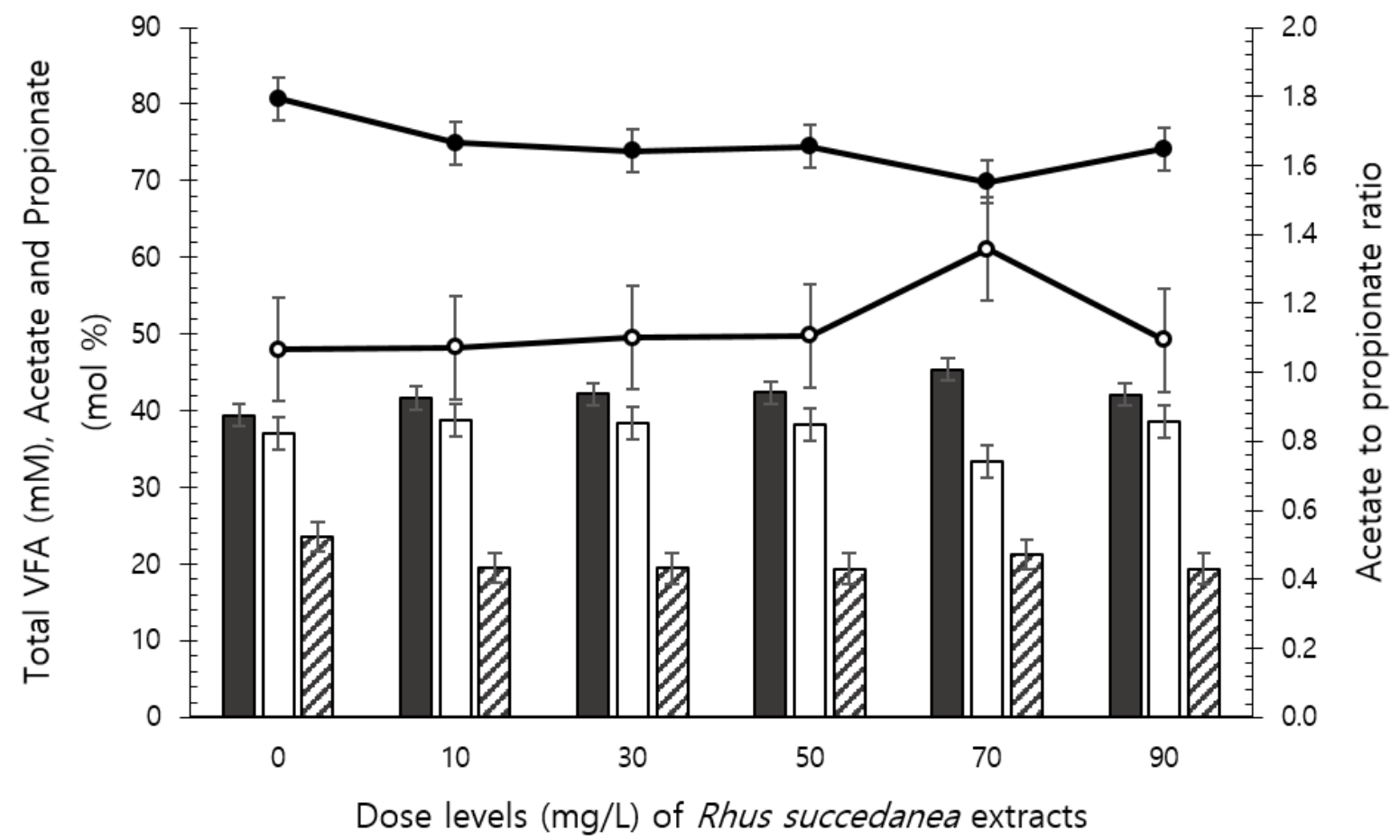

Figure 1. In vitro ruminal fermentation characteristics at $24 \mathrm{~h}$ incubation by different doses of Rhus succedanea extracts. Total volatile fatty acid (filled circle), acetate to propionate ratio (open circle), acetate (solid bar), propionate (open bar), and butyrate (hatched bar) concentrations. Error bars are standard error of the mean. 
Table 4. Effects of different doses of Rhus succedanea extracts on in vitro cumulative methane production by mixed rumen anaerobic microbial fermentation

\begin{tabular}{|c|c|c|c|c|c|c|c|c|c|c|}
\hline \multirow{2}{*}{ Incubation time (h) } & \multicolumn{6}{|c|}{ Dose (mg/L) } & \multirow{2}{*}{ SEM } & \multicolumn{3}{|c|}{ Contrast } \\
\hline & 0 & 10 & 30 & 50 & 70 & 90 & & Linear & Quadratic & Cubic \\
\hline \multicolumn{11}{|c|}{ Methane production (mL/g DM of substrate) } \\
\hline $3 \mathrm{~h}$ & 0.29 & 0.25 & 0.24 & 0.25 & 0.23 & 0.23 & 0.03 & 0.211 & 0.591 & 0.631 \\
\hline $6 \mathrm{~h}$ & 0.68 & 0.52 & 0.61 & 0.57 & 0.64 & 0.68 & 0.05 & 0.390 & 0.131 & 0.385 \\
\hline $9 \mathrm{~h}$ & 1.02 & 1.05 & 0.95 & 0.85 & 0.79 & 0.91 & 0.05 & 0.004 & 0.058 & 0.064 \\
\hline $12 \mathrm{~h}$ & 1.27 & 0.73 & 1.07 & 1.06 & 1.08 & 1.10 & 0.09 & 0.596 & 0.341 & 0.060 \\
\hline $24 \mathrm{~h}$ & 2.19 & 2.18 & 1.58 & 1.59 & 1.51 & 1.51 & 0.08 & $<0.0001$ & 0.002 & 0.598 \\
\hline $48 \mathrm{~h}$ & 6.26 & 7.92 & 6.83 & 4.28 & 4.99 & 4.77 & 0.26 & $<0.0001$ & 0.291 & $<0.001$ \\
\hline $72 \mathrm{~h}$ & 10.49 & 12.42 & 10.29 & 11.92 & 10.93 & 10.66 & 0.44 & 0.458 & 0.298 & 0.852 \\
\hline
\end{tabular}

SEM, standard error of the mean, $n=3 ; D M$, dry matter.

\section{DISCUSSION}

Total gas production was closely related to the digestion of fermentation substrates, VFA production, and microbial activity and growth [13]. Ruminal microbial activity was affected by the use of plant extracts and secondary plant metabolites [14]. In the present study, EGP decreased in response to the increasing doses of Rhus succedanea extracts. Similarly, $\mathrm{E}_{\mathrm{DM}}$ linearly decreased with increasing $R$. succedanea extract doses. However, the rate of the decrease in $\mathrm{E}_{\mathrm{GP}}$ in response to the dose of $R$. succedanea extracts tended to slow at $50 \mathrm{mg} / \mathrm{L}$ dosing of $R$. succedanea extracts (quadratic effect: $\mathrm{p}=0.069$ ). Similarly, total VFA concentration was decreased following 48 and $72 \mathrm{~h}$ incubations (quadratic effect: $\mathrm{p}=0.021$; linear effect: $\mathrm{p}=0.014$ ). Busquet et al [14] reported that at the highest concentrations of various plant extracts, most treatments showed decreased total VFA production, possibly reflecting decreased feed digestion. Plant secondary metabolites are particularly attractive as rumen modifiers that are generally accepted to be environmental friendly and safe to use in food production systems. Due to their potential to adversely affect feed intake and nutrient utilization, however, these should be administered at low concentrations to beneficially alter ruminal fermentation. The effect of $R$. succedanea extract dose on ammonia- $\mathrm{N}$ concentration was quadratic $(p=0.003)$ following $24 \mathrm{~h}$ and $48 \mathrm{~h}$ incubations, and this effect was increased for $50 \mathrm{mg} / \mathrm{L}$ extracts and decreased for $70 \mathrm{mg} / \mathrm{L}$ extracts. These results suggest that changes observed to be caused by $R$. succedanea extract on ruminal ammonia-N concentration may be contradictory depending on the dose used. The observed reduction in am-

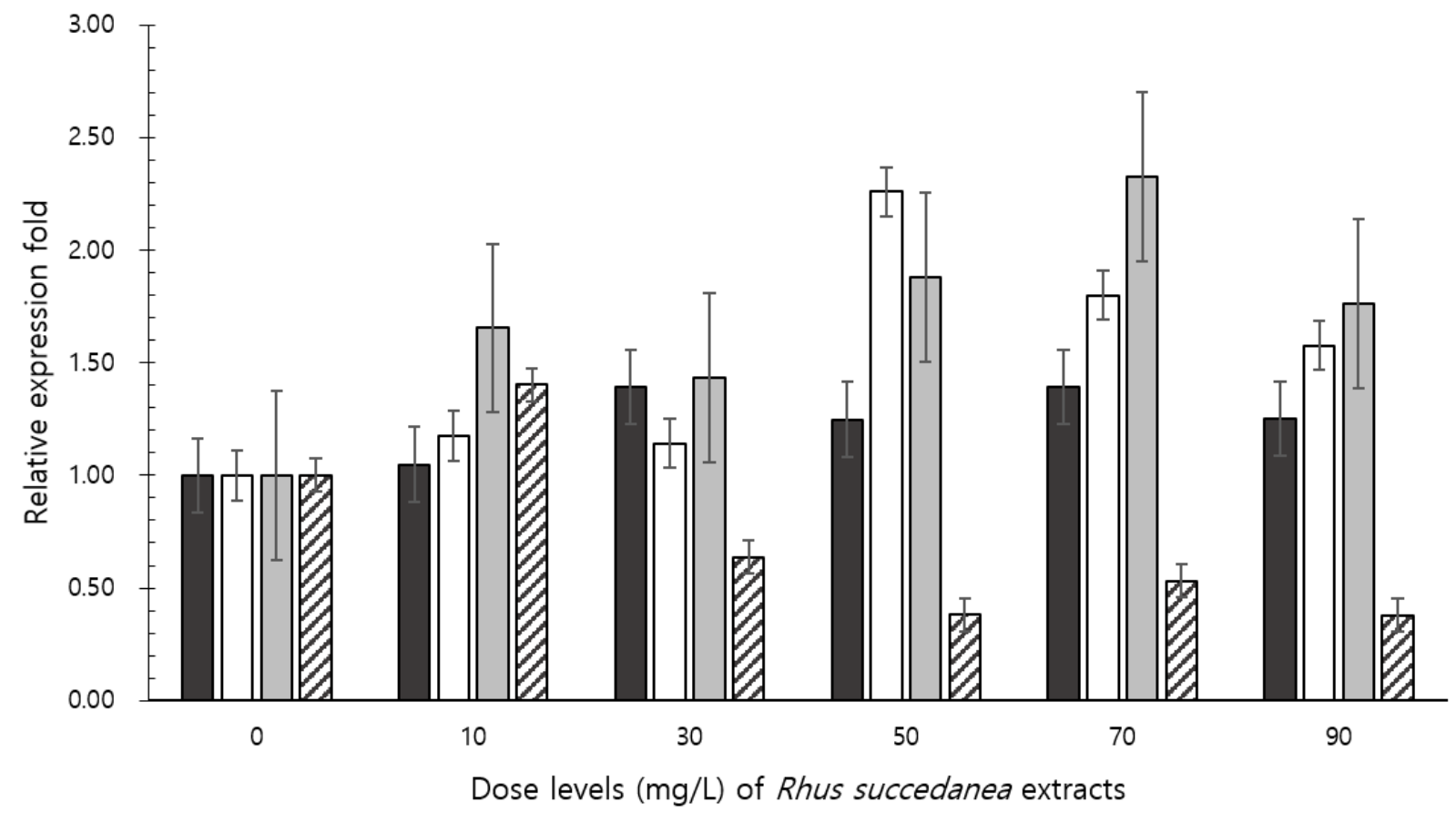

Figure 2. Relative quantification of in vitro rumen microbial populations at $24 \mathrm{~h}$ incubation by different doses of Rhus succedanea extracts. Ruminococcus albus (black bar), Fibrobacter succinogenes (white bar), Ruminococcus flavefaciens (grey bar), and methanogenic archaea (hatched bar). Error bars are standard error of the mean. 
monia-N suggests that over $70 \mathrm{mg} / \mathrm{L}$ of $R$. succedanea extracts reduced amino acid deamination. Inhibition of amino acid deamination has practical implications because it may increase ruminal use of dietary protein and improve the efficiency of $\mathrm{N}$ use in the rumen [15].

Ruminal cellulolysis is conducted primarily by Fibrobacter succinogenes, Ruminococcus flavefaciens, and Ruminococcus albus [16], and their relative populations can potentially impact the ratios of VFA available to ruminants. In the present study, an increase in ruminal acetate concentration was observed to accompany the addition of $70 \mathrm{mg} / \mathrm{L}$ dose of $R$. succedanea extracts, and this was consistent with the observed increase in abundance of the gram-negative bacteria Fibrobacter succinogenes. This bacterium intensively degrades plant cell walls by an erosion-like mechanism, in which it burrows its way through the complex matrix of cellulose and hemicellulose in the cell wall resulting in the release of digestible and undigested cell wall fragments [17]. Ruminococcus flavefaciens, a gram-positive bacteria, was also observed to increase with addition of $70 \mathrm{mg} / \mathrm{L}$ dose of $R$. succedanea extract that corresponded with the increase of acetate concentration. Production of methane and propionate are negatively correlated because both these processes compete for hydrogen [18]. However, the negative relationship between propionate concentration and methane output was not evident from our results. Formation of acetate and butyrate results in production of additional methanogenic substrates, which are formate and hydrogen, and propionate formation results in less hydrogen being available for methane production [18]. In addition, low methane production might be related to reduced fiber digestibility, thus, also influencing the energy input to the animal. In the present study DM degradability and gas production linearly decreased, whereas Fibrobacter succinogenes and Ruminococcus flavefaciens, which are considered to be primarily responsible for plant cell wall biodegradation, increased after $24 \mathrm{~h}$ of incubation. Nevertheless, the decreasing methane production and abundance of methanogenic archaea observed with extract dosing were likely caused by the combined effects of decreased total VFA concentration and decreased DM fermentation. $R$. succedanea produces a cytotoxic biflavonoid, and it has been reported that the methanol extract of Rhus succedanea showed positive indications of the presence of phenols, steroids, alkaloids, flavonoids, tannins, glycosides, and carbohydrates [19]. It has been documented that alkaloids, flavonoids, tannins, and phenols are plant secondary metabolites, which are well-known for their antimicrobial activity in the rumen. The extract of stem bark of Rhus had antioxidant effects against hydroxyl radicals and antiproliferative activity against human cancer cell lines, and also augmented the activity of cell-associated detoxifying enzymes in hepatocytes [20-22]. The sap of the wax tree (R. succedanea) is composed of urushiol, glycoprotein, flavonoids, a gummy substance that contains laccase, stellacyanin, polysaccharides, peroxidase, and water [23]. Therefore, the observed antibacterial potency of methanol extracts from $R$. succedanea can be attributed to the nature of its biologically active components, which might be enhanced in the rumen. However, further work is needed to clarify the relationship between fibrolytic microbes and methanogens, and although suppression of methanogenic archaea by $R$. succedanea extracts was observed in this study, it must be noted that the long-term effects of the extracts might be different because adaptation of the rumen microbes might occur.

\section{CONFLICT OF INTEREST}

We certify that there is no conflict of interest with any financial organization regarding the material discussed in the manuscript.

\section{ACKNOWLEDGMENTS}

Support for this research was provided by the National Research Foundation of Korea Grant Funded by the Korean Government (NRF-2015R1A6A1A03031413).

\section{REFERENCES}

1. Chalupa, W. Manipulation of rumen fermentation. In: Haresign W, Cole D, editors. Recent advances in animal nutrition. London, England: Butterworths; 1984. p. 143-60.

2. Chopra RN, Chopra IC, Handa KI, Kapoor LD. Chopra's indigenous drugs of India. 2nd ed. Calcutta, India: U. N. Dhur \& Sons Private Ltd; 1956. p. 377, p. 575.

3. Kim TH, Lee KM, Kwon KR, Choi SM. A literature study on lacquer poison. Korean Pharmacopuncture Inst 2002;5:159-69.

4. Kim YS, Liang CY, Song YH, Lee SK. Effects of dietary Rhus verniciflua stokes supplementation on meat quality characteristics of Hanwoo (Korean Cattle) beef during refrigerated storage. Asian-Australas J Anim Sci 2006;19:113-8.

5. McDougall EI. Studies on ruminant saliva. 1. The composition and output of sheep's saliva. Biochem J 1948;43:99-109.

6. Zafarian R, Manafi M. Effect of garlic powder on methane production, rumen fermentation and milk production of buffaloes. Annu Rev Res Biol 2013;3:1013-9.

7. Denman SE, McSweeney CS. Development of a real-time PCR assay for monitoring anaerobic fungal and cellulolytic bacterial populations within the rumen. FEMS Microbiol Ecol 2006;58: 572-82.

8. Koike S, Kobayashi Y. Development and use of competitive PCR assays for the rumen cellulolytic bacteria: Fibrobacter succinogenes, Ruminococcus albus and Ruminococcus flavefaciens. FEMS Microbiol Lett 2001;204:361-6.

9. Skillman LC, Toovey AF, Williams AJ, Wright AD. Development and validation of a real-time PCR method to quantify 
rumen protozoa and examination of variability between entodinium populations in sheep offered a hay-based diet. Appl Environ Microbiol 2006;72:200-6.

10. Denman SE, Tomkins NW, McSweeney CS. Quantitation and diversity analysis of ruminal methanogenic populations in response to the antimethanogenic compound bromochloromethane. FEMS Microbiol Ecol 2007;62:313-22.

11. Ørskov ER, McDonald I. The estimation of protein degradability in the rumen from incubation measurements weighted according to rate of passage. J Agric Sci 1979;92:499-503.

12. NRC. Nutrient requirements of dairy cattle. 6th rev. ed. Washington, DC, USA: National Academy Press; 1989.

13. Getachew G, Robinson PH, DePeters EJ, Taylor SJ. Relationships between chemical compositions, dry matter degradation and in vitro gas production of several ruminant feeds. Anim Feed Sci Technol 2004;111:57-71.

14. Busquet M, Calsamiglia S, Ferret A, Kamel C. Plant extracts affect in vitro rumen microbial fermentation. J Dairy Sci 2006; 89:761-71.

15. Van Nevel CJ, Demeyer DI. Manipulation of rumen fermentation. In: Hobson PN, editor. The rumen microbial ecosystem. London, UK: Elsevier Applied Science; 1988. p.387-443.

16. Dehority BA. Microbial ecology of cell wall fermentation. In: Jung HG, Buxton DR, editors. Forage cell wall structure and digestibility. Hat ${ }^{\circ}$ eld \& J. Ralph. Madison, WI, USA: American Society of Agronomy/Crop Science Society of America/Soil
Science Society of America; 1993. p. 425-53.

17. Jun HS, Qi M, Ha JK, Forsberg CW. Fibrobacter succinogenes, a dominant fibrolytic ruminal bacterium: Transition to the post genomic era. Asian-Australas J Anim Sci 2007;20:802-10.

18. Moss AR, Jouany JP, Newbold J. Methane production by ruminants: its contribution to global warming. Ann Zootech 2000; 49:231-53.

19. Shrestha S, Subaramaihha SR, Subbaiah SG, Eshwarappa RS, Lakkappa DB. Evaluating the antimicrobial activity of methonolic extract of rhus succedanea leaf gall. Bioimpacts 2013;3: 195-8.

20. Kitts DD, Lim KT. Antitumorigenic and cytotoxic properties of an ethanol extract derived from Rhus verniciflua Stokes (RVS). J Toxicol Environ Health Part A 2001;64:357-71.

21. Lee JC, Kim J, Lim KT, Yang MS, Jang YS. Ethanol eluted extract of Rhus verniciflua Stokes showed both antioxidant and cytotoxic effects on mouse thrombocytes depending on the dose and time of the treatment. BMB Rep 2001;34:250-8.

22. Lim KT, Lee JC, Jung HY, Jo SK. Effects of Rhus verniciflua Stokes (RVS) on cell associated detoxificant enzymes and glucose oxidase-mediated toxicity in cultured mouse hepatocytes. Toxicol Res 2000;16:125-31.

23. Yang J, Du Y, Huang R, Wan Y, Li T. Chemical modification, characterization and structure-anticoagulant activity relationships of Chinese lacquer polysaccharides. Int J Biol Macromol 2002;31:55-62. 